International Journal of Automotive and Mechanical Engineering (IJAME)

ISSN: 2229-8649 (Print); ISSN: 2180-1606 (Online);

Volume 13, Issue 3 pp. 3773 - 3787, December 2016

CUniversiti Malaysia Pahang Publishing

DOI: https://doi.org/10.15282/ijame.13.3.2016.19.0309

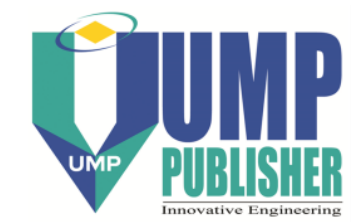

\title{
The effect of injection timing on the performance and emission of direct injection CI engine running on diethyl ether-diesel blends
}

\author{
K.R. Patil ${ }^{1, *}$ and S.S. Thipse ${ }^{2}$ \\ ${ }^{1}$ Faculty of Mechanical Engineering, \\ Marathwada Mitra Mandal's College of Engineering, Karvenagar, \\ Pune, 411052, India. \\ *Email: krpatil@mmcoe.edu.in \\ ${ }^{2}$ The Automotive Research Association of India (ARAI), Pune, India.
}

\begin{abstract}
In diesel engine, fuel injection timing is a major parameter that affects combustion, performance and emission characteristics. Variation in injection timing has a strong effect on BTE, BSFC, BSEC, smoke and NOx emissions because of the change in maximum pressure and temperature in engine cylinder. In this experimental investigation, the optimum performance DEE-diesel blend ratio DE15D (15\% DEE and 85\% diesel by volume) was tested for variable injection timings to evaluate its effect and determine the optimum fuel injection timing, as the addition of DEE to diesel fuel causes retardation in dynamic injection timing. The engine tests were carried out at 10\%, 25\%, 50\%, $75 \%$ and $100 \%$ of full load with $3^{\circ}$ and $6^{\circ}$ advancement, base and $3^{\circ}$ and $7^{\circ}$ retarded injection timings. The test results show that BSFC and BSEC provide the best result for the base injection timing at full load condition. The $6^{\circ}$ advancement in injection timing at full load condition reduced smoke by $12.5 \%$ and $\mathrm{HC}$ by $15.38 \%$. The retarded injection timing by $7^{\mathrm{o}}$ at full load showed improvement in BTE by $7.96 \%$ and in NOx by $3.66 \%$.
\end{abstract}

Keywords: Diethyl ether-diesel blend; CI engine; variable injection timing; performance; emissions characteristics.

\section{INTRODUCTION}

Energy shortage and environmental protections have stimulated research on reducing fuel consumption, exhaust emissions and engine noise while increasing engine specific outputs. Research work on alternative fuels, especially oxygenated bio-resource fuels, have been explored worldwide [1-4]. Oxygenated fuels like Diethyl ether (DEE) and Dimethyl ether (DME) are attracting remarkable attention from researchers as clean alternative fuels for CI engines [5, 6]. DEE is a promising oxygenated renewable biobased resource fuel. The blending of DEE with diesel enriches the oxygen content and cetane number of fuel-air mixture as compared to those of diesel fuel [7]. It has been shown that DEE addition supplies extra amount of oxygen for fuel blends, which influences combustion, performance and emissions characteristics of the engine [8-10]. In the experimental research work performed by [11], diethyl ether (DEE) of 2\%, 5\%, $8 \%, 10 \%, 15 \%, 20 \%$ and $25 \%$ (by volume) were blended into diesel. The effects of different blend ratios on combustion, performance and emissions of the engine were evaluated and the optimum performance blend ratio was identified. As stated by [11], with up to $15 \%$ DEE by volume in the blends, the engine ran smoothly, but with more than $15 \%$ DEE, erratic engine operations with some instability and fluctuations were seen 
in engine speed and power output under partial load condition. Thus, it was necessary to provide continuous adjustment in the fuel injection pump rack, which could affect the output results. Hence, based on the combustion, performance and emission analyses, the optimum and most favorable DEE-diesel blend ratio was DE15D (15\% DEE and 85\% Diesel by volume) without any modification on the engine. Similar results were reported by researchers like $[12,13]$.

Fuel injection timing essentially controls the crank angle at which combustion starts. While the state of the air into which the fuel is injected changes as injection timing is varied and thus ignition delay would vary, these effects are predictable. If injection starts earlier (advanced injection timing), initial air temperature and pressure are lower and so the ignition delay would increase. If injection starts later (retarded injection timing), air temperature and pressure are slightly higher initially, and a decrease in ignition delay would occur. This means that injection timing variation has a strong effect on ignition delay, and consequently on engine combustion and emissions because of the changing maximum pressure and temperature in engine cylinder [14]. Patil and Thipse [11] reported that the addition of DEE to diesel fuel causes retardation of dynamic injection timing due to problems encountered with fuel pump and lowers density and viscosity of DEE-diesel blends. The retarded injection timing is due to lower bulk modulus of compressibility, or speed of sound, of the fuel blend, which leads to slower transfer of pressure wave from the fuel pump to the injector needle and late needle lift $[15,16]$. Thus, the start of combustion is postponed and ignition delay is increased. Similar results were reported by [17]. Hence, a detail study about injection timing variation related to combustion and emissions are required. Moreover, it was necessary to find out the optimum injection timing. Hence, in this study, the optimum performance blend DE15D was selected for variable injection timing tests.

\section{METHODS AND MATERIALS}

\section{Experimental Fuel and Its Properties}

The conventional diesel was purchased from a local commercial representative and DEE (otherwise called 'ethyl ether' or more simply 'ether') was procured from an authorized representative and was certified to have a purity of $\geq 99.5 \%$ (analytical grade). The detail on DEE production can be referred from [18]. DEE and diesel fuel (by volume) were blended in different proportions by manual mixing at room temperature. The evaluation tests of blended fuels including miscibility tests and characterization were carried out. The various physicochemical properties of the neat diesel fuel (D100), neat DEE fuel (DEE100) and their blends were measured in the laboratory according to the IS 1448 standard test methods and the results are summarised in Table 1. Results show that DEE is completely miscible with diesel in any proportion. The oxygen content and cetane number of the blends increased, while the density, kinematic viscosity and calorific value of the blends decreased with the concentration of DEE with diesel $[18,19]$. This shows that the blended fuel retains the desirable physical properties of diesel fuel, but includes the cleaner burning capability of DEE. The replacement of diesel by DEE above 25\% (by volume) in DEE-diesel blends is not practicable, as far as the desirable properties of diesel engine fuel are concerned. Though, beyond 25\% DEE-diesel blend, the viscosity and density of the blended fuel reduces to lesser than the acceptable limit, which affects the lubricity to a certain limit and causes excessive leakages and vapor locks in the fuel injection system [12]. 
Table 1. Physicochemical properties of DEE-diesel blend fuels [18].

\begin{tabular}{|c|c|c|c|c|c|c|c|}
\hline \multirow{2}{*}{$\begin{array}{l}\text { Fuel } \\
\text { blend }\end{array}$} & \multicolumn{2}{|c|}{$\begin{array}{l}\text { Distillation } \\
\text { recovery }\end{array}$} & \multirow{2}{*}{$\begin{array}{l}\text { Kinematic } \\
\text { Viscosity } \\
@ 40^{\circ} \mathrm{C} \\
(\mathrm{cSt})\end{array}$} & \multirow{2}{*}{$\begin{array}{l}\text { Density } \\
\text { @ } 15^{\circ} \mathrm{C} \\
\left(\mathrm{kg} / \mathrm{m}^{3}\right)\end{array}$} & \multirow{2}{*}{$\begin{array}{l}\text { Net calorific } \\
\text { value } \\
(\mathrm{MJ} / \mathrm{kg})\end{array}$} & \multirow{2}{*}{$\begin{array}{l}\text { Cetane } \\
\text { number }\end{array}$} & \multirow{2}{*}{$\begin{array}{l}\text { Oxygen } \\
\text { content } \\
\text { (wt. \%) }\end{array}$} \\
\hline & $\begin{array}{l}\text { IBP } \\
\left({ }^{\circ} \mathrm{C}\right)\end{array}$ & $\begin{array}{l}\text { FBP } \\
\left({ }^{\circ} \mathrm{C}\right)\end{array}$ & & & & & \\
\hline D100 & 146 & 374 & 2.45 & 836 & 43.26 & 52 & 0 \\
\hline DE100 & - & - & 0.23 & 713 & 27.76 & 125 & 21.6 \\
\hline DE15D & 36 & 377 & 1.67 & 817 & 41.23 & 62.95 & 2.82 \\
\hline $\begin{array}{l}\text { Test } \\
\text { methods }\end{array}$ & \multicolumn{2}{|c|}{ IS 1448 P:18 } & $\begin{array}{l}\text { IS } 1448 \\
P: 25\end{array}$ & $\begin{array}{l}\text { IS } 1448 \\
\mathrm{P}: 16\end{array}$ & $\begin{array}{l}\text { IS } 1448 \text { P:6 } \\
\& \text { P:7 }\end{array}$ & - & - \\
\hline
\end{tabular}

\section{Experimental Set Up and Procedure}

Experiments were conducted on a single cylinder, four stroke, naturally aspirated, water cooled, DI diesel engine. The fuel injection system used in this research work is as given by the manufacturer. It has a single barrel fuel injection pump and inline fuel injector with a three holed nozzle, located near the centre of the combustion chamber with an opening pressure of 20.5 MPa. The specifications of the engine are listed in Table 2. The engine test rigs are were designed and developed to measure the performance, emission and combustion parameters. Figure 1 shows the physical experimental set up. The engine test rig design includes selection of dynamometer, exhaust system compatible for measurement of emissions, gravimetric fuel consumption measurement to reduce the effect of density variation, air flow measurement system, speed and load measurement systems along with its fine control, innovative cooling system to maintain uniform engine temperature, calorimeter to measure heat balance, high speed data collection and combustion analysis system including cylinder pressure sensor, crank angle encoder, data acquisition card, and data processing software.

Table 2. Specifications of test engine.

\begin{tabular}{ll}
\hline Engine type & Single cylinder, 4-stroke, water-cooled, DI \\
\hline Model & Kirloskar, TV1 model \\
Aspiration & Naturally aspirated \\
Bore x Stroke & $87.5 \mathrm{~mm}$ x 110 mm \\
Connecting rod & $234 \mathrm{~mm}$ \\
Displacement & 0.661 litre \\
Compression ratio & $18: 1$ \\
Rated power & $3.7 \mathrm{~kW}$ \\
Rated speed & $1500 \mathrm{rpm}$ \\
Fuel injection system & Single barrel F.I. pump, Inline fuel injector \\
Fuel injection timing & $23^{\circ} \mathrm{BTDC}$ (static) \\
Inj. opening pressure & $20.5 \mathrm{MPa}$ \\
Injector holes & $3 \times 0.288 \mathrm{~mm}$ \\
\hline
\end{tabular}

To measure the concentrations of $\mathrm{NOx}, \mathrm{CO}, \mathrm{CO}_{2}, \mathrm{HC}$ and $\mathrm{O}_{2}$ in the exhaust emissions an AVL Digas 444 exhaust gas analyzer was used. It measured the $\mathrm{CO}, \mathrm{CO}_{2}$ and $\mathrm{HC}$ emissions with spectrum analysis principle and $\mathrm{NO}$ and $\mathrm{O}_{2}$ by the electrochemical sensors. An AVL 437 smoke meter was used to measure the smoke intensity. During the 
experiments engine coolant and calorimeter temperatures were measured by RTD's and the exhaust gas temperature by ' $\mathrm{K}$ ' type thermocouples. Initially, the experimental results of the neat diesel fuel were validated with standard results and then other tests were carried out. The main specification and resolution of the measurement devices are given in Table 3.

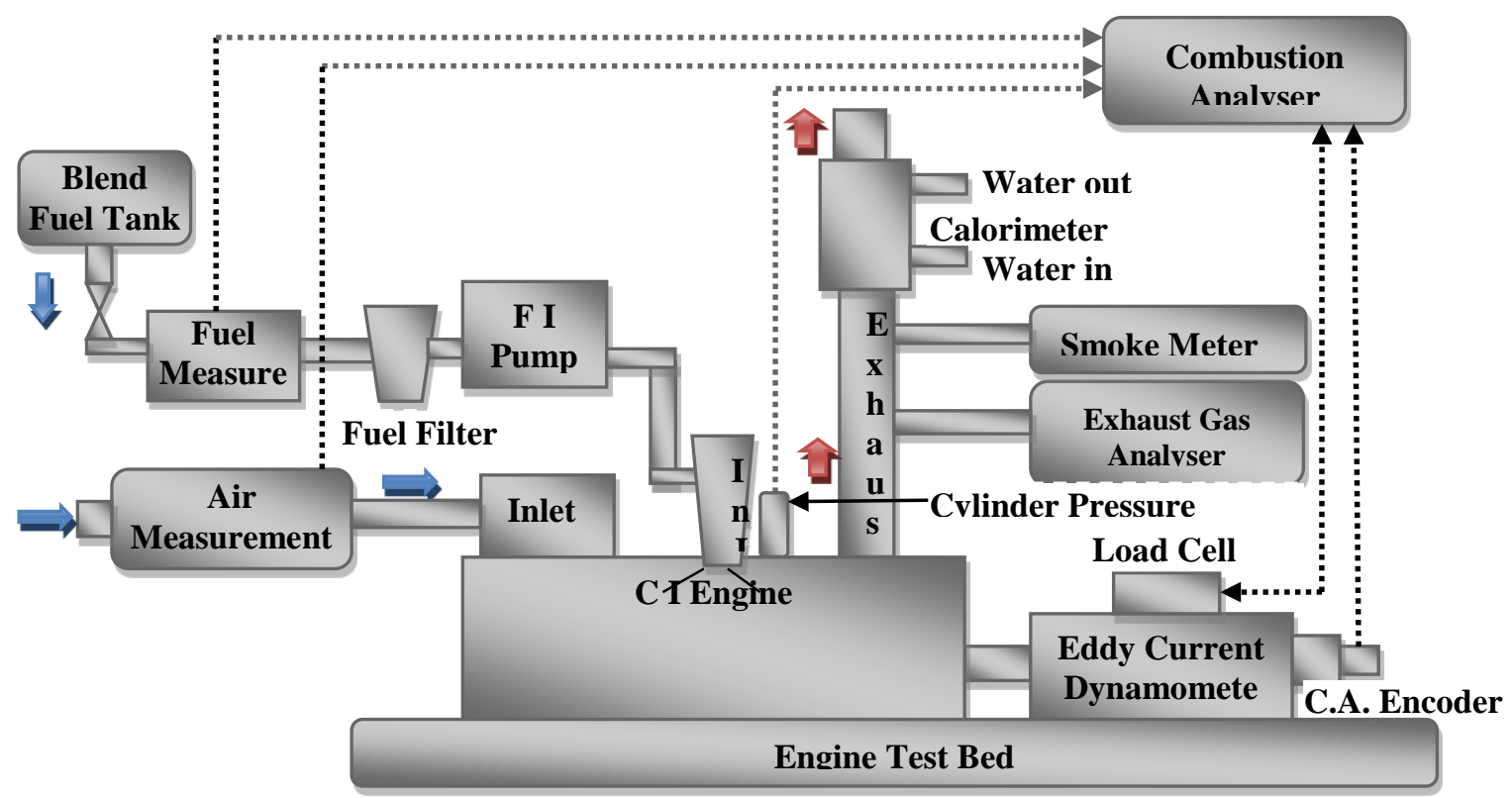

Figure 1. Physical experimental set up.

Table 3. Specification and resolution of the measurement devices.

\begin{tabular}{|c|c|c|c|}
\hline Instrumentation & Parameter & Measurement range & Resolution \\
\hline \multirow[t]{5}{*}{ AVL DiGas 444} & $\mathrm{HC}$ & 0-20000 ppm volume & $\begin{array}{l}\leq 2000: 1 \mathrm{ppm} \text { volume } \\
>2000: 10 \mathrm{ppm} \text { volume }\end{array}$ \\
\hline & $\mathrm{CO}$ & $0-10 \%$ by volume & $0.01 \%$ by volume \\
\hline & $\mathrm{CO}_{2}$ & $0-20 \%$ by volume & $0.1 \%$ by volume \\
\hline & $\mathrm{O}_{2}$ & $0-22 \%$ by volume & $0.01 \%$ by volume \\
\hline & NO & 0-5000 ppm by volume & 1 ppm by volume \\
\hline \multirow{2}{*}{$\begin{array}{l}\text { AVL } 437 \text { smoke } \\
\text { meter }\end{array}$} & Opacity & $0-100$ in $\%$ & $\pm 1 \%$ full scale reading \\
\hline & $\begin{array}{l}\text { K value } \\
\text { (absorption) }\end{array}$ & $0-99.99 \mathrm{~m}^{-1}$ & $\pm 1 \%$ full scale reading \\
\hline $\begin{array}{l}\text { Piezo sensor } \\
\text { (PCB }\end{array}$ & $\begin{array}{l}\text { Cylinder } \\
\text { Pressure }\end{array}$ & $0-350$ bar & 0.007 bar \\
\hline Piezotronics) & & & \\
\hline $\begin{array}{l}\text { Crank angle } \\
\text { sensor (Kubler) }\end{array}$ & Crank angle & $20-5500 \mathrm{rpm}$ & 1 degree with TDC pulse \\
\hline
\end{tabular}

The standard setting of the engine used was with four shims to give a standard injection timing of $23^{\circ}$ BTDC. By inserting shims of different thicknesses between the fuel injection pump body and engine body, the injection timings were varied. Experiments were conducted with $3^{\circ}$ and $6^{\circ}$ advancement, normal and $3^{\circ}$ and $7^{\circ}$ retarded injection timings for optimizing the fuel injection timing for DE15D blend fuel. The engine tests 
were carried out at $10 \%, 25 \%, 50 \%, 75 \%$ and $100 \%$ full load at $1500 \mathrm{rpm}$ rated speed and 20.5 MPa injection pressure for all injection timings.

\section{RESULTS AND DISCUSSION}

\section{Brake Thermal Efficiency}

Brake thermal efficiency indicates the ability of a combustion system to accept the test fuel, and provides comparable means of assessing how efficiently the energy in the fuel is converted into mechanical power output [20]. Ignition delay and combustion characteristics are very sensitive to changes in injection timings, as the temperature and pressure changes significantly close to TDC [21-23].
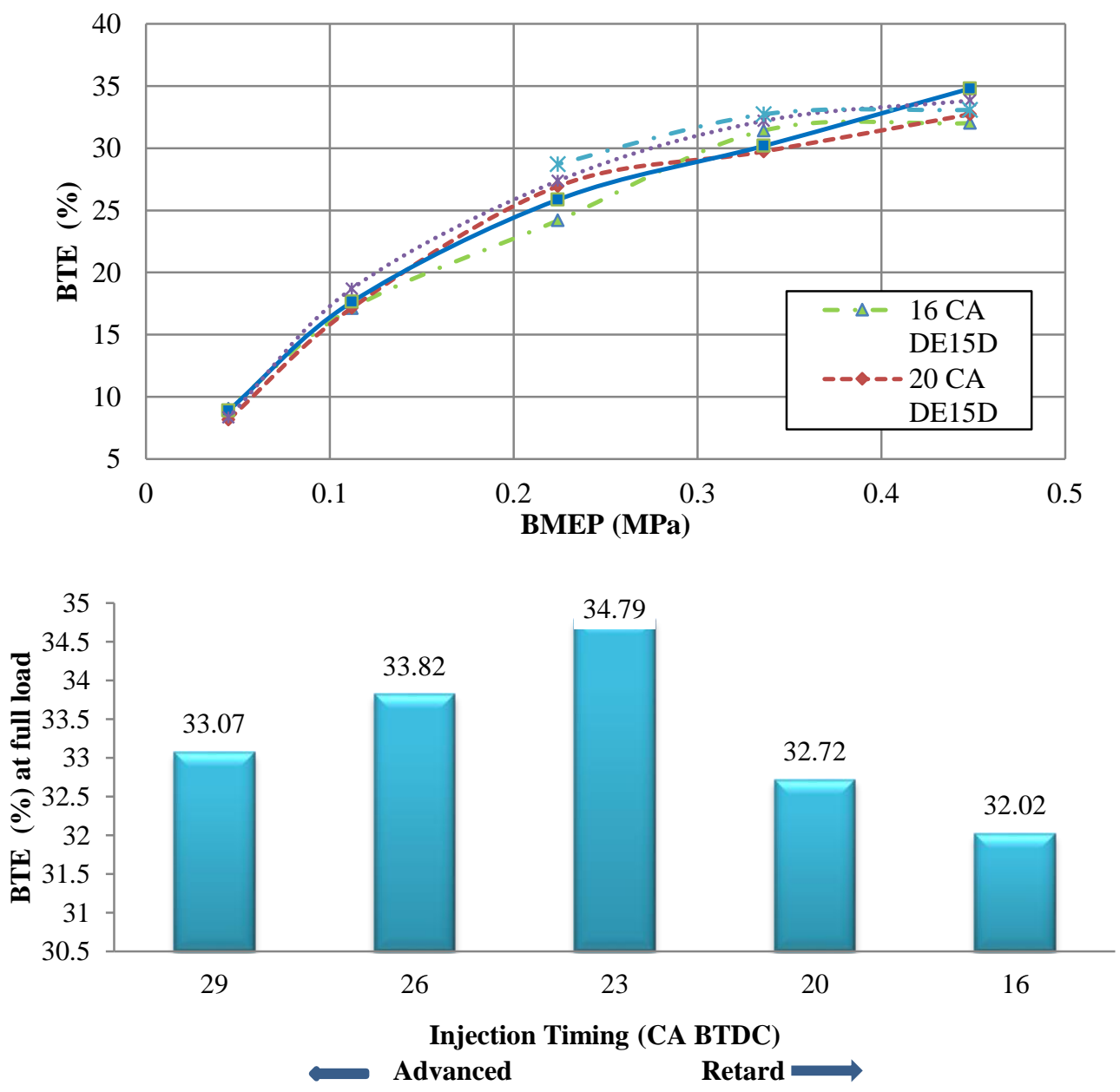

Figure 2. Effect of variable injection timing on brake thermal efficiency for optimum

DEE-diesel blend

Figure 2 illustrates the variation of BTE with respect to the BMEP of DE15D blend for variable injection timing at $1500 \mathrm{rpm}$. It can be seen from the figure that, overall, BTE values improved by advancing injection timing with except at full load condition. Retarded injection timing diminished BTE values for all the loads compared to base injection timing. Injection timing plays crucial role in the start and quality of combustion. The addition of DEE to diesel fuel leads to retarded dynamic injection timing and start of 
heat release rate. To compensate for this late injection and combustion, the injection timing needs to be advanced. If injection is delayed, the temperature and pressure would be slightly higher initially, but decrease with longer delay, resulting in incomplete combustion, reduced power output and poor fuel conversion efficiency. This affects the Brake Thermal Efficiency. The optimal injection timing based on BTE for all the loads was 26 CA BTDC and at full load condition, the base injection timing shows the best result for DE15D blend. Retarded or advanced injection timing may diminish BTE values due to incomplete combustion. The most favorable conditions for ignition lie in between.

\section{Brake Specific Fuel Consumption}

Figure 3 illustrates the variation in brake specific fuel consumption (BSFC) with respect to the BMEP of DE15D blend for variable injection timing at $1500 \mathrm{rpm}$. It can be seen from figure that, overall, BSFC values reduced with variable injection timing except at full load condition. At full load condition, the BSFC of base injection timing was slightly lower than other injection timings. This shows that at full load condition, the base injection timing gives the best result for DE15D blend. It was revealed that DEE has higher oxygen content and cetane number, compared to those of diesel fuel. DEE addition supplies an amount of oxygen for fuel blends, which influences engine combustion and emissions. It may be due to improved combustion in the fuel-rich zone due to the presence of oxygenate. As BSFC measures how efficiently an engine uses the supplied fuel to produce work. It is inversely proportional to the brake thermal efficiency of the engine. Therefore, lower value of BSFC indicates higher overall efficiency of an engine [24].
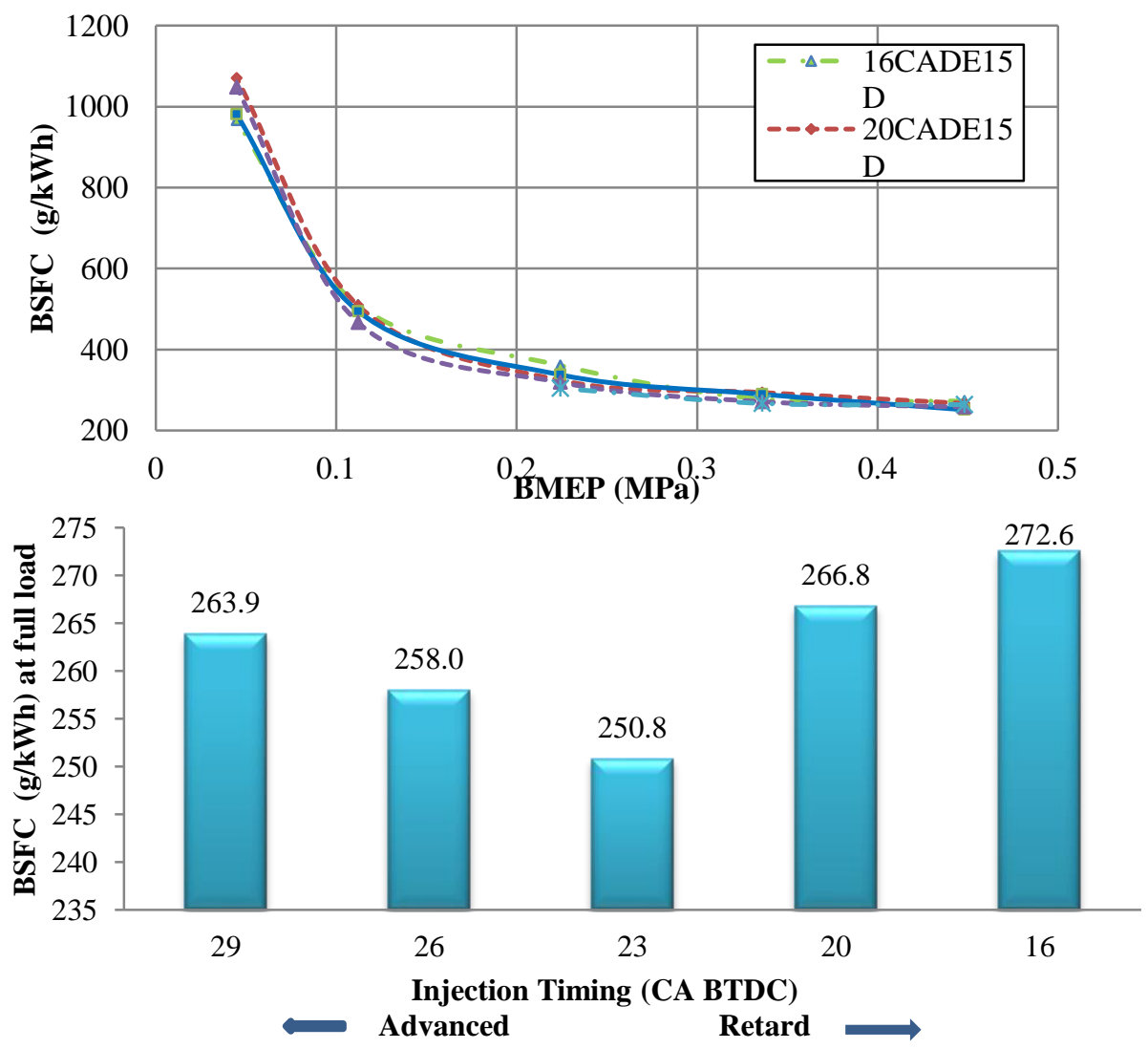

Figure 3. Effect of variable injection timing on BSFC for optimum DEE-diesel blend 


\section{Brake Specific Energy Consumption}

As the net calorific value of DEE is about two thirds of that of diesel, and as stated earlier, the addition of DEE to diesel fuel causes retarded dynamic injection timing due to problems encountered with fuel pump and lowers the density and viscosity of the blends, the brake specific energy consumption (BSEC) was calculated and utilised to make a comparison among the variable injection timings for optimized DE15D blend fuel. Figure 4 illustrates the variation in BSEC with respect to the BMEP of DE15D blend for variable injection timings at $1500 \mathrm{rpm}$. It can be seen from the figure that, overall, BSEC values reduced with advanced injection timing except at full load condition. At full load condition, the BSEC for base injection timing was lower than other injection timings. This shows that at full load condition, the base injection timing gives the best result for DE15D blend. These observations are similar to the findings for BSFC.
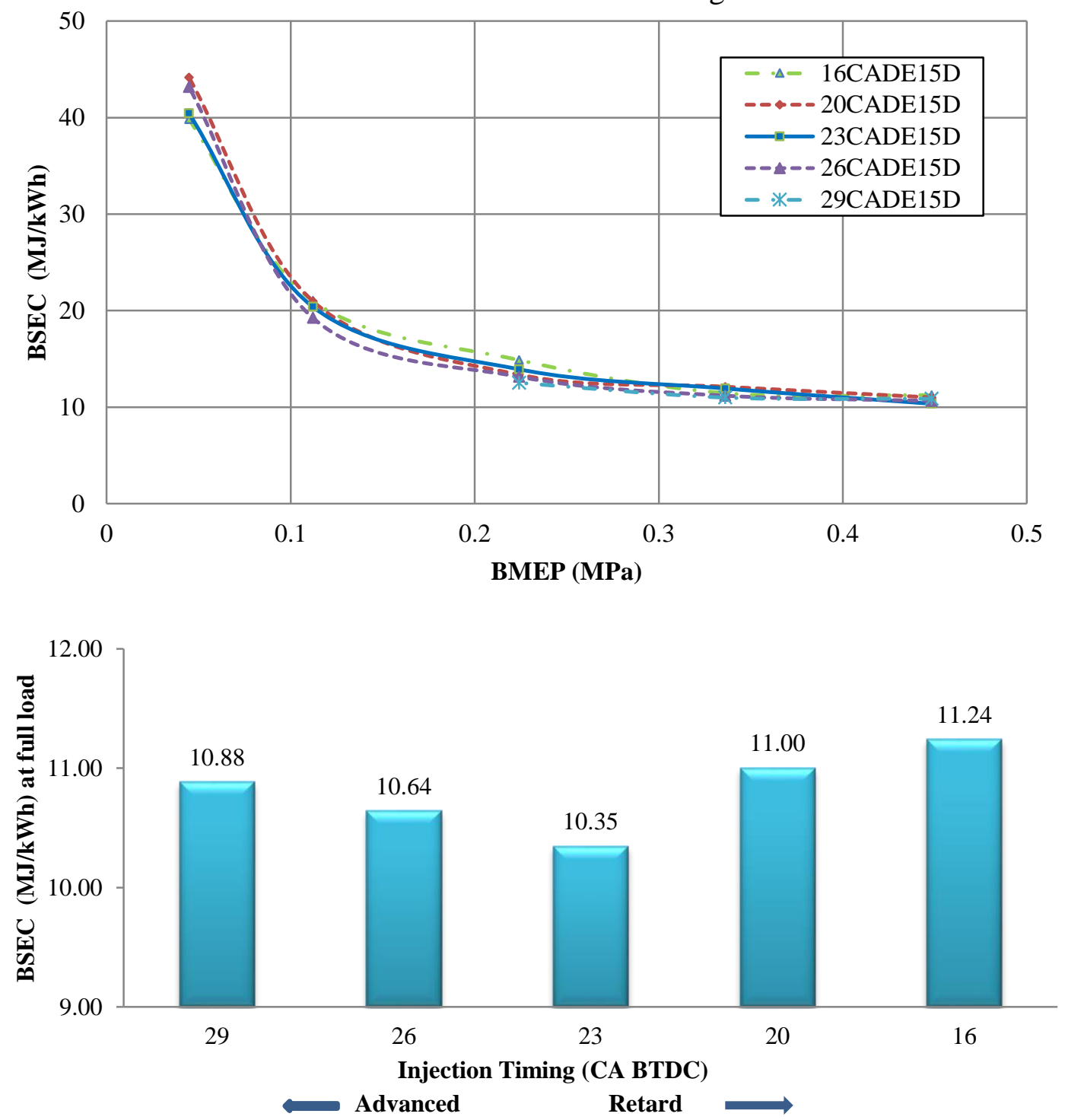

Figure 4. Effect of variable injection timing on BSEC for optimum DEE-diesel blend

\section{Smoke Emission}

The variation in smoke opacity versus BMEP for variable injection timing of DE15D blend are displayed in Figure 5. It can be seen that the overall trend of the graph displayed minor reduction in smoke opacity due to advanced injection timing. It seems that the 
advancement of injection timing provides enough time for mixing injected fuel with compressed air; it increases the cylinder temperature during the expansion stroke and provides more time for soot particles oxidation, which leads to reduced smoke [25]; [26]. Retarded injection timing shows a noticeable increase in smoke opacity. According to the results obtained, the optimum injection timing based on smoke opacity was 29 CA BTDC at full load condition.
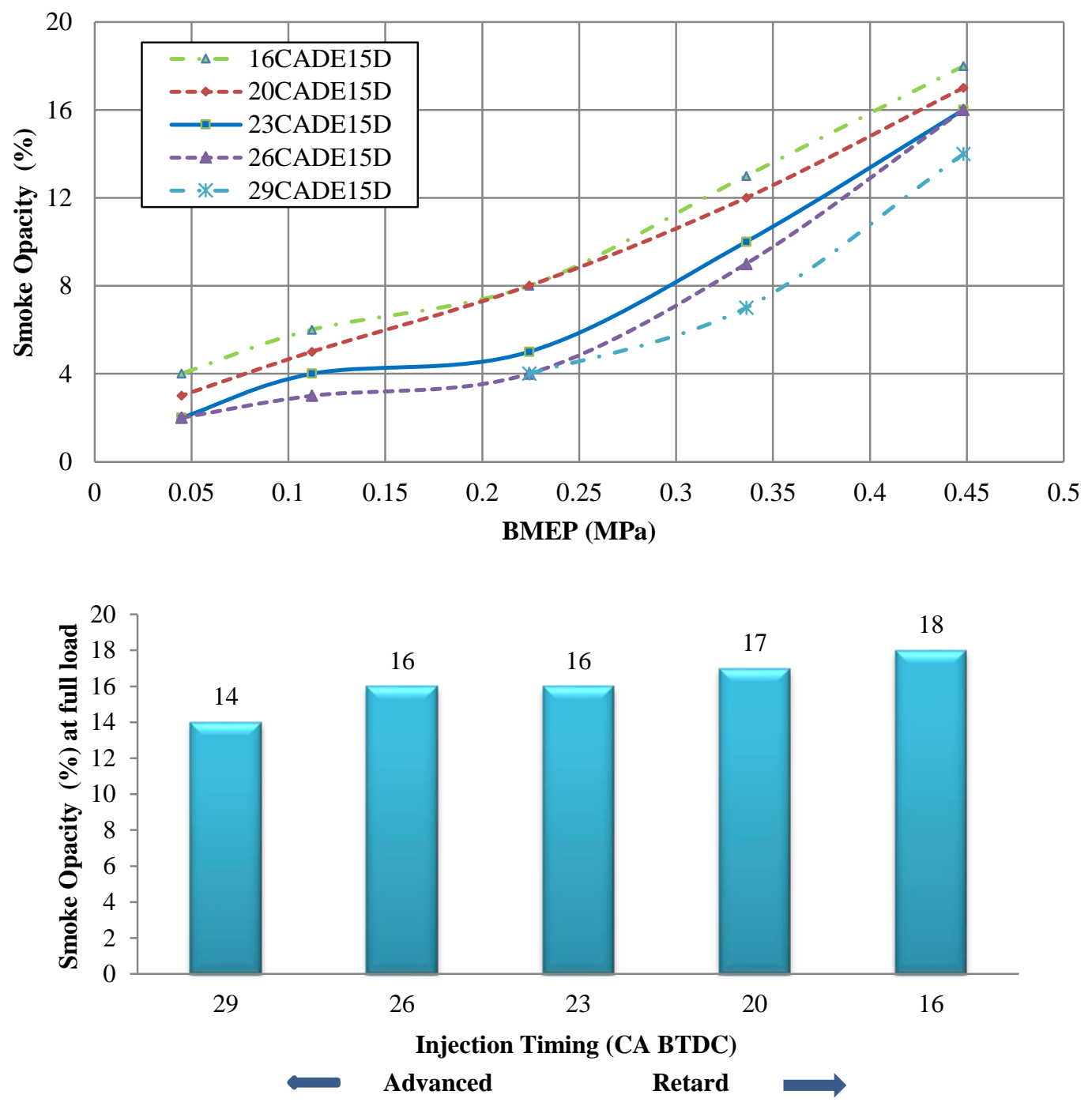

Figure 5. Effect of variable injection timing on smoke opacity for optimum DEE-diesel blend

\section{NOx Emission}

In direct injection diesel engine, variable injection timing has a strong effect on NOx emissions [27]. NOx refers to a class of compound called nitrogen oxide, which usually represents a mixture of $\mathrm{NO}$ and $\mathrm{NO}_{2}$. In diesel engine exhaust, $\mathrm{NO}$ is usually the most abundant NOx and constitutes more than $70-90 \%$ of total NOx $[28,29]$. In this study, only NO was measured and the readings of NO represented the NOx emissions. The various factors like availability of oxygen, combustion temperature, nitrogen content of the fuel itself and the reaction time determine NOx emission during the combustion process. The production of NOx is proportional to combustion efficiency. Better 
combustion efficiency has higher value of exhaust temperature, which increases the level of NOx production [30]. Most of the techniques to reduce NOx emission depend on the reduction in peak flame temperature. The peak flame temperature can be reduced by various methods like retarded injection timing, exhaust gas recirculation (EGR), split injection, water injection into the engine's intake manifold and use of alternative fuels $[15,23,31,32]$.
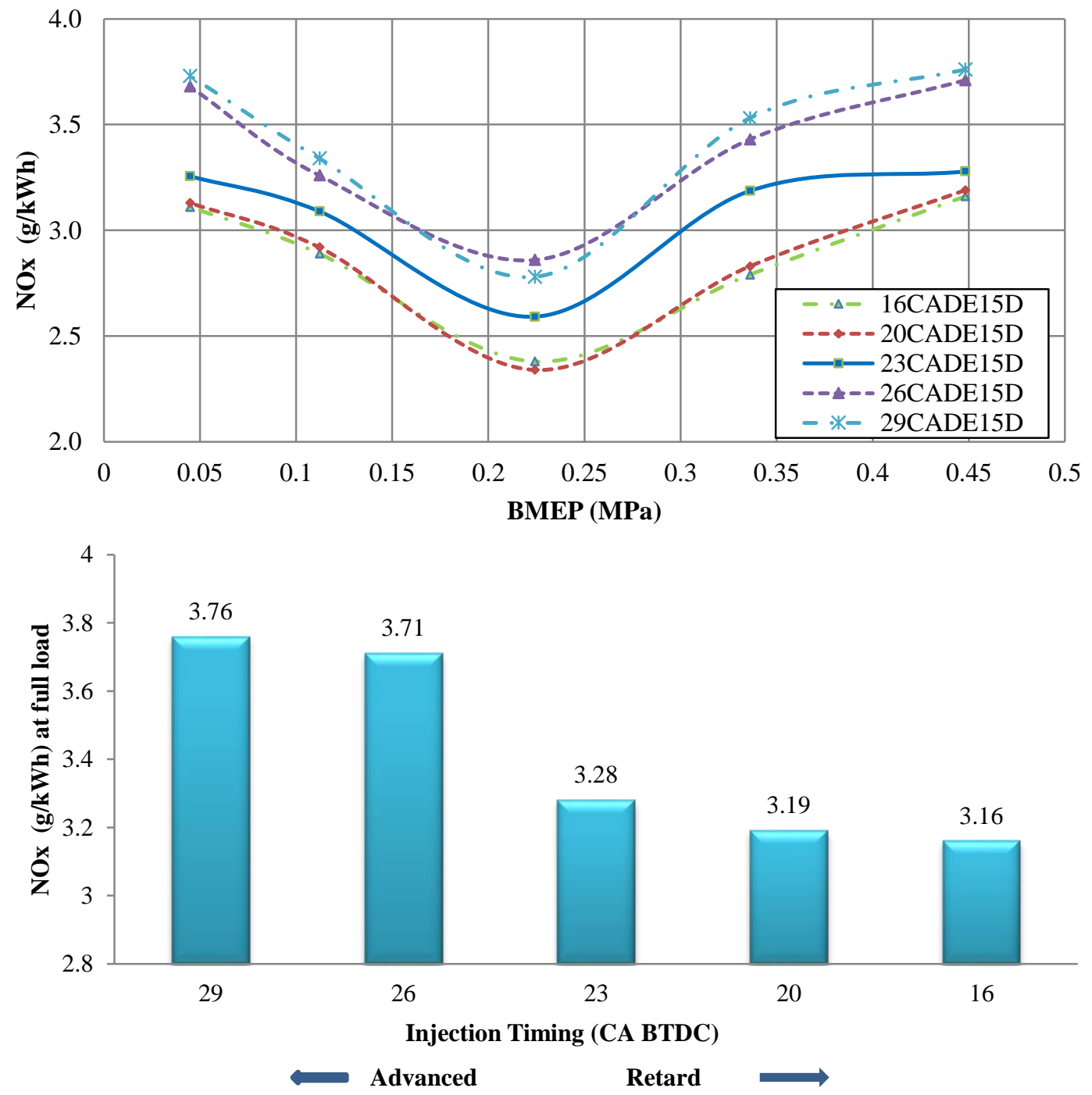

Figure 6. Effect of variable injection timing on NOx emission for optimum DEE-diesel blend

The variation in NOx emissions versus BMEP for variable injection timing of DE15D blend is displayed in Figure 6. As illustrated in the figure, the advancement of injection timing for optimum blend fuel shows increased NOx emission. In advanced injection timing, the fuel is injected into compressed air having lower temperature. It extends the ignition delay period. Longer ignition delay period causes more fuel to be injected during that period, and better mixing of fuel and air. This means that, the earlier fuel is injected, the longer ignition delay and the greater the premixed portion of the fuel prior to ignition leads to higher NOx formation [20, 27, 33]. Retarded injection timing shows the opposite effect of a sharp decrease in NOx emission as expected due to reduced 
peak pressure and temperature. Overall, the optimum injection timing based on NOx emission was 16 CA BTDC for DE15D optimum blend. Although advanced injection timing increases NOx emission, the amount of NOx did not show a significant difference compared to the base injection timing at full load condition.

\section{Carbon Monoxide Emission}

The emission of carbon monoxide (CO) from a direct injection diesel engine mainly depends on the physicochemical properties of the fuel [34]. Figure 7 illustrates the variation in carbon monoxide emission with respect to BMEP of DE15D blend for variable injection timing at $1500 \mathrm{rpm}$. Retarded injection timing shows a noticeable increase in $\mathrm{CO}$ emission, while advanced injection timing shows a reduction in $\mathrm{CO}$ emission. $\mathrm{CO}$ emission followed the same trend of smoke emission by the engine due to the same physicochemical properties affecting qualitatively in the same manner. No significant difference was observed in $\mathrm{CO}$ emission at full load condition for the varied injection timing of DE15D blend.
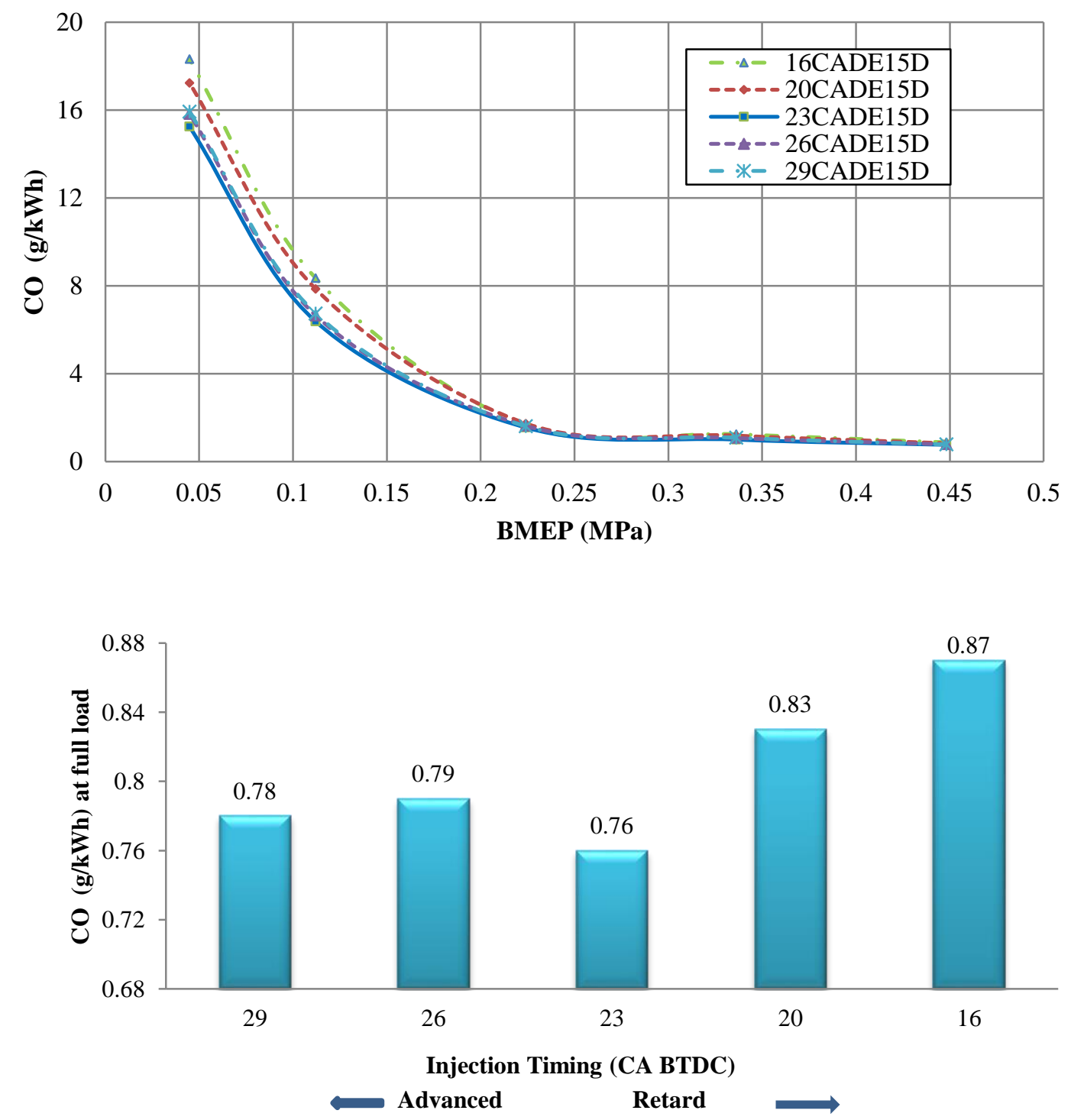

Figure 7. Effect of variable injection timing on CO emission for optimum DEE-diesel blend 


\section{Unburned Hydrocarbon Emission}

The variation in unburned hydrocarbon (HC) emission versus BMEP for variable injection timing of DE15D blend are displayed in Figure 8. As illustrated in the figure, advanced injection timing for optimum blend fuel shows reduced $\mathrm{HC}$ emission. Overall, at full load condition in DI diesel engine, $\mathrm{HC}$ emission was low and varied modestly with injection timing. At lighter loads, $\mathrm{HC}$ emission was higher and it increased as injection became specifically retarded from optimum [35]. The general trend of $\mathrm{HC}$ emission reduction was observed in the results with advanced injection timing. Higher amount of $\mathrm{HC}$ emission was evident between the base injection timing with retarded injection timing. Almost the same trend was seen from Figure 8 for different injection timings. According to these figures, it was revealed that 29 CA BTDC was the best injection timing based on HC emission.
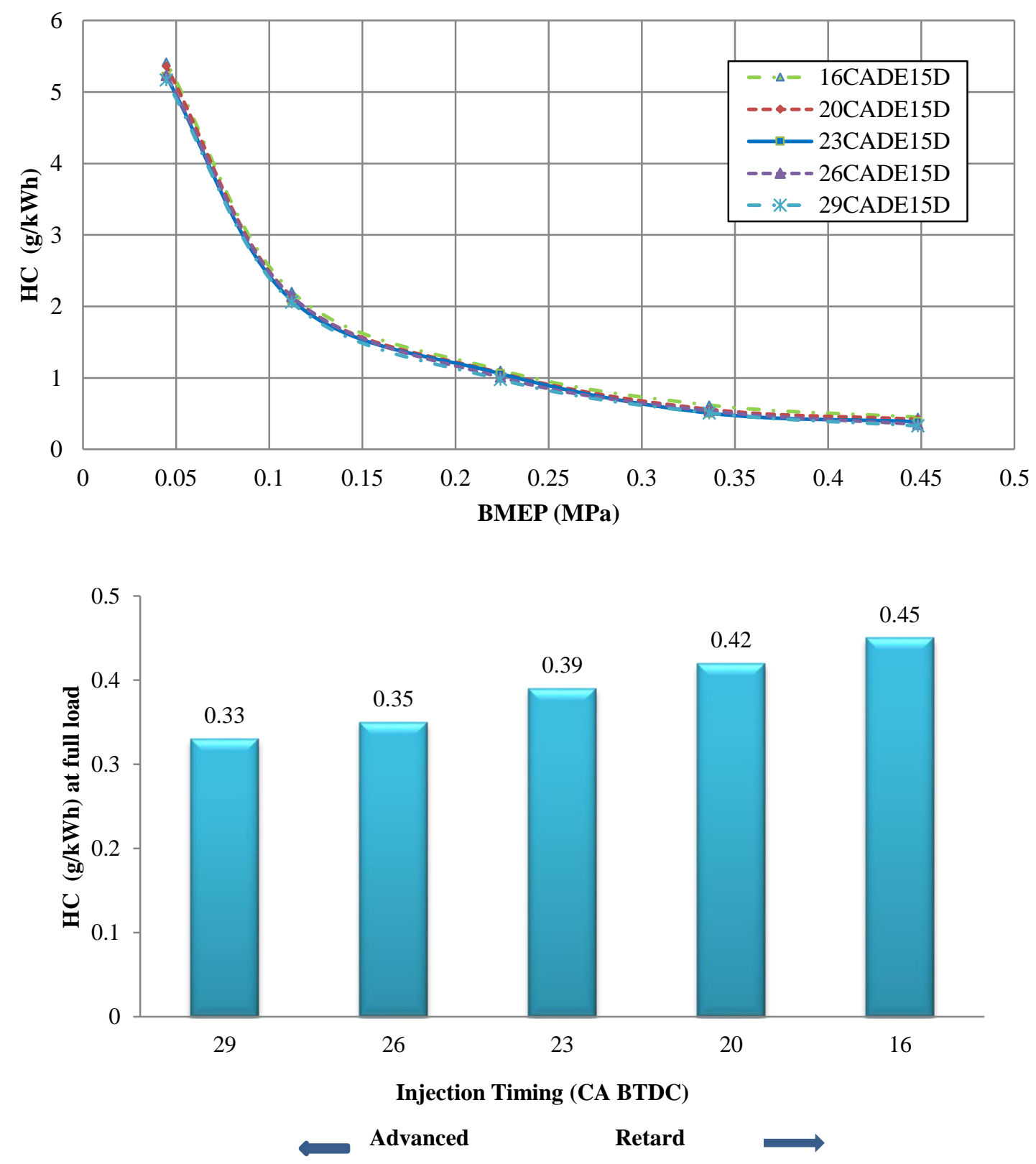

Figure 8. Effect of variable injection timing on $\mathrm{HC}$ emissions for optimum DEE-diesel blend 


\section{CONCLUSIONS}

Diethyl Ether (DEE) is a promising oxygenated and cetane improver renewable bio-based resource fuel for diesel engines as a clean alternative fuel. The optimum DEE-diesel blend DE15D was tested for variable injection timings to evaluate its effect and to determine the optimum fuel injection timing. The normal injection timing 23 CA BTDC was varied and the experiments were conducted for $3^{\circ}$ and $6^{\circ}$ advancement, normal and $3^{\circ}$ and $7^{\circ}$ retarded injection timings. The following conclusions are obtained.

i) BTE values improved by advancing injection timing, except at full load condition. Retarded injection timing diminished the BTE values for all the loads compared to the base injection timing. At full load condition, the BSFC of base injection timing was slightly lower than other injection timings. At full load condition, the BSEC of base injection timing reduced compared to other injection timings and gave the best result for DE15D blend.

ii) Advanced injection timing reduced smoke opacity, while retarded injection timing increased smoke opacity. The optimum injection timing based on smoke opacity at full load condition was 29 CA BTDC. The advancement of injection timing increased NOx emission, while the retarded injection timing showed the opposite effect with a sharp decrease in NOx emissions.

iii) $\mathrm{CO}$ emissions increased compared to the base injection timing over all injection timings. There was no significant difference observed in $\mathrm{CO}$ emissions at full load condition for varied injection timing. The general trend in $\mathrm{HC}$ emission reduction was observed for advanced injection timing. Higher amount of $\mathrm{HC}$ emission with retarded injection timing than the base injection timing was evident.

In summary, on the basis of the above conclusions, it can be summarised that advanced injection timing at $29 \mathrm{CA}$ BTDC reduced smoke and $\mathrm{HC}$ emissions, and the retarded injection timing at $16 \mathrm{CA}$ BTDC reduced BTE and NOx emissions.

\section{ACKNOWLEDGEMENTS}

This research work was done in I. C. Engines Laboratory, M. M. College of Engineering, Pune, India. The authors would like to acknowledge the test bed facility provided by MMCOE, equipment support extended by VIT, Pune and fuel test facility provided by Automotive Materials Laboratory, ARAI, Pune and CHEM-TECH Laboratories Ltd., Pune, India.

\section{REFERENCES}

[1] Jaichandar S, Annamalai K. Jatropha oil methyl ester as diesel engine fuel - an experimental investigation. International Journal of Automotive and Mechanical Engineering. 2016;13:3248-61.

[2] Vashist D, Ahmad M. Statistical Analysis of Diesel Engine Performance for Castor and Jatropha Biodiesel-Blended Fuel. International Journal of Automotive and Mechanical Engineering. 2014;10:2155-69.

[3] Adam IK, A. Aziz AR, Yusup S. Determination of Diesel Engine Performance Fueled Biodiesel (Rubber Seed/Palm Oil Mixture) Diesel Blend. International Journal of Automotive and Mechanical Engineering. 2015;11:2675-85. 
[4] Khalid A, Jaat N, Sapit A, Razali A, Manshoor B, Zaman I, et al. Performance and Emissions Characteristics of Crude Jatropha Oil Biodiesel Blends in a Diesel Engine. International Journal of Automotive and Mechanical Engineering. 2015;11:2447-57.

[5] Sezer İ. Thermodynamic, performance and emission investigation of a diesel engine running on dimethyl ether and diethyl ether. International Journal of Thermal Sciences. 2011;50:1594-603.

[6] Weberdemenezes E, Dasilva R, Cataluna R, Ortega R. Effect of ethers and ether/ethanol additives on the physicochemical properties of diesel fuel and on engine tests. Fuel. 2006;85:815-22.

[7] Roy MM, Calder J, Wang W, Mangad A, Diniz FCM. Cold start idle emissions from a modern Tier-4 turbo-charged diesel engine fueled with diesel-biodiesel, diesel-biodiesel-ethanol, and diesel-biodiesel-diethyl ether blends. Applied Energy. 2016;180:52-65.

[8] Miller Jothi NK, Nagarajan G, Renganarayanan S. LPG fueled diesel engine using diethyl ether with exhaust gas recirculation. International Journal of Thermal Sciences. 2008;47:450-7.

[9] Kaimal VK, Vijayabalan P. An investigation on the effects of using DEE additive in a DI diesel engine fuelled with waste plastic oil. Fuel. 2016;180:90-6.

[10] Yasin MHM, Mamat R, Aziz A, Yusop AF, Ali MH. Investigation on combustion parameters of palm biodiesel operating with a diesel engine. Journal of Mechanical Engineering and Sciences. 2015;9:1714-26.

[11] Patil KR, Thipse SS. Experimental investigation of CI engine combustion, performance and emissions in DEE-kerosene-diesel blends of high DEE concentration. Energy Conversion and Management. 2015;89:396-408.

[12] Górski K, Przedlacki M. Evaluation of the Influence of Diethyl Ether (DEE) Addition on Selected Physicochemical Properties of Diesel Oil and Ignition Delay Period. Energy \& Fuels. 2014;28:2608-16.

[13] Ibrahim A. Investigating the effect of using diethyl ether as a fuel additive on diesel engine performance and combustion. Applied Thermal Engineering. 2016;107:853-62.

[14] Rostami S, Ghobadian B, Kiani Deh Kiani M. Effect of the Injection Timing on the Performance of a Diesel Engine Using Diesel-Biodiesel Blends. International Journal of Automotive and Mechanical Engineering. 2014;10:1945-58.

[15] Subramanian KA. A comparison of water-diesel emulsion and timed injection of water into the intake manifold of a diesel engine for simultaneous control of NO and smoke emissions. Energy Conversion and Management. 2011;52:849-57.

[16] Mohan B, Yang W, Chou Sk. Development of an accurate cavitation coupled spray model for diesel engine simulation. Energy Conversion and Management. 2014;77:269-77.

[17] Mohanan P, Kapilan N, Reddy RP. Effect of diethyl ether on the performance and emission of A4 - Sdi diesel engine. SAE Techni Paper. 2003.

[18] Patil KR, Thipse SS. Characterisation of the key fuel properties of oxygenated diethyl Ether-Diesel blends. International Symposium on Engineering and Technology, ISET 2014. Pune: Trans Tech Publications Ltd; 2014. p. 175-80.

[19] Bailey B, Eberhardt J, Goguen S, Erwin J. Diethyl ether (DEE) as a renewable diesel fuel. International Fall Fuels and Lubricants Meeting and Exposition. 1997.

[20] Heywood JB. Internal combustion engine fundamentals. New York, N.Y.: McGraw-Hill; 1988. 
[21] Xing-cai L, Jian-guang Y, Wu-gao Z, Zhen H. Effect of cetane number improver on heat release rate and emissions of high speed diesel engine fueled with ethanoldiesel blend fuel. Fuel. 2004;83:2013-20.

[22] Boehman AL, Morris D, Szybist J, Esen E. The impact of the bulk modulus of diesel fuels on fuel injection timing. Energy and Fuels. 2004;18:1877-82.

[23] Kettner M, Dechent S, Hofmann M, Huber E, Arruga H, Mamat R, et al. Investigating the influence of water injection on the emissions of a diesel engine. Journal of Mechanical Engineering and Sciences. 2016;10:1863-81.

[24] Rakopoulos DC, Rakopoulos CD, Giakoumis EG, Dimaratos AM. Characteristics of performance and emissions in high-speed direct injection diesel engine fueled with diethyl ether/diesel fuel blends. Energy. 2012;43:214-24.

[25] Rakopoulos DC, Rakopoulos CD, Giakoumis EG, Dimaratos AM. Studying combustion and cyclic irregularity of diethyl ether as supplement fuel in diesel engine. Fuel. 2013;109:325-35.

[26] Ali OM, Mamat R, Masjuki HH, Abdullah AA. Analysis of blended fuel properties and cycle-to-cycle variation in a diesel engine with a diethyl ether additive. Energy Conversion and Management. 2016;108:511-9.

[27] Sathiyamoorthi R, Sankaranarayanan G. Fuel Injection Timings of a Direct Injection Diesel Engine Running on Neat Lemongrass Oil-Diesel Blends. International Journal of Automotive and Mechanical Engineering. 2015;11:234863.

[28] Gonca G. Investigation of the effects of steam injection on performance and NO emissions of a diesel engine running with ethanol-diesel blend. Energy Conversion and Management. 2014;77:450-7.

[29] Shukri MR, Rahman MM, Ramasamy D, Kadirgama K. Artificial Neural Network Optimization Modeling on Engine Performance of Diesel Engine Using Biodiesel Fuel. International Journal of Automotive and Mechanical Engineering. 2015;11:2332-47.

[30] Palash SM, Kalam MA, Masjuki HH, Arbab MI, Masum BM, Sanjid A. Impacts of NOx reducing antioxidant additive on performance and emissions of a multicylinder diesel engine fueled with Jatropha biodiesel blends. Energy Conversion and Management. 2014;77:577-85.

[31] Patil KR, Thipse SS. Characteristics of Performance and Emissions in a Directinjection Diesel Engine Fuelled with Kerosene/Diesel Blends. International Journal of Automotive and Mechanical Engineering. 2014;10:2102-11.

[32] Mahalakshmi NV, Anand R. Simultaneous reduction of NO $\langle$ sub $\rangle\langle i\rangle x</ i\rangle\langle/$ sub $\rangle$ and smoke from a direct-injection diesel engine with exhaust gas recirculation and diethyl ether. Proceedings of the Institution of Mechanical Engineers, Part D: Journal of Automobile Engineering. 2007;221:109-16.

[33] Stone R. Introduction to internal combustion engines. Houndmills [etc.]: MacMillan Press; 2012.

[34] Liaquat AM, Masjuki HH, Kalam MA, Varman M, Hazrat MA, Shahabuddin M, et al. Application of blend fuels in a diesel engine. Energy Procedia. 2012;14:1124-33.

[35] Thipse SS. Alternative fuels : concepts, technologies and developments. Ahmedabad: Jaico Pub. House; 2010. 


\section{Nomenclature}

ASTM american standards for testing materials FBP final boiling point

BMEP brake mean effective pressure HC hydrocarbon

BTDC before top dead centre IBP initial boiling point

BSEC brake specific energy consumption LCV lower calorific value

BSFC brake specific fuel consumption NO nitric oxide

BTE brake thermal efficiency $\mathrm{NO}_{2}$ nitric dioxide

CA crank angle NOx oxides of nitrogen

CI compression ignition NTP normal temp. and pressure

$\mathrm{CO}$ carbon monoxide $\quad \mathrm{PM}$ particulate matter

$\mathrm{CO}_{2}$ carbon dioxide RTD resistance temp. detector

DI direct injection SI spark ignition

DEE diethyl ether TDC top dead centre

EGR exhaust gas recirculation 